\section{The Segment}

However diffuse or referred deep pain may be, its distribution follows always a segmental pattern (Kellgren, 1938). The same pattern fits the deep tenderness as well as the muscular rigidity that accompanies the pain. If in embryonic life the injured tissue has migrated from its first relative position to another segment, the pain still extends along the segment from which the tissue has migrated and to which it has remained attached by its innervation. This is exemplified typically by the pain from a lesion to the central part of the diaphragm whose area of diffusion lies in the area of distribution of the third and fourth cervical nerves.

Within the affected segment the direction of the diffusion of deep pain is determined more by the level of the segment than by the situation of the injured spot in the segment. Thus in a thoracic segment the pain is felt anteriorly even if the injury is situated as far backwards as an interspinous ligament. In the last thoracic and in the upper two or three lumbar segments there is hardly any space anatomically for an anterior diffusion, and deep injury at this level causes backache. In the upper cervical segments the direction is predominantly posterior to the occiput; in the lower cervical it is predominantly anterior to the arms.

This extension of pain in an anterior or posterior direction occurs the same whether the pain is visceral or somatic in origin. As already stated, renal colic and interspinous injury give pain with identical distribution. Backache can be caused by a lesion in a pelvic viscus or in a somatic structure. With thoracic or abdominal pain there is a tendency to look for visceral lesions and to forget somatic causes; and, in lumbar pain, to look for somatic and forget about visceral lesions. This tendency probably arises from the greater frequency of visceral lesions in thoracic or abdominal pain and of somatic lesions in lumbar pain; but it is wise to be "segmentally minded" and to investigate all structures within the segment in every case.

\section{Visceral Pain}

The viscera lie, as a rule, so deep within the segments that they are well protected and do not therefore respond to the stimuli that provoke pain ordinarily in the somatic tissues. Many viscera are completely insensitive, and any pain that is associated with them is caused by an extension of the lesion to adjacent tissues, as to the parietal peritoneum or to the retroperitoneum. Other viscera are sensitive, but their stimuli must be appropriate to them, and their pain has the same characters and is probably furthered by the same mechanism as somatic pain. Embryologically these viscera are intimately connected with the somatic tissues. They arise entirely from the mesoderm, from each side of the segment; they are paired, or have been paired during some period of their embryonic life. Examples are the kidneys and the heart.

There is still another group of viscera. These are hollow organs which have never been paired, but have had always a mesial attachment and have included ectoderm in their cavities. Pain from these organs has distinct characters. It is exemplified typically by the pain of obstruction from a stenosing carcinoma of the colon. The appropriate stimulus is related to the spasm, which is a response to the stretching provoked by the obstacle. This pain, in quality, is not different. from deep pain, and can be simulated by injecting hypertonic saline in the abdominal rectus muscles, but it is never accompanied by muscular rigidity or by tenderness of any kind; hence compression of the wall and active movements are not resented, and the patient may press his abdomen, bend, and writhe about restlessly in a vain attempt to obtain relief (Morley, 1937). The pain is diffuse, but even when maximal it remains always mesial and never extends beyond the abdominal wall to the limbs. Its distribution is segmental (Brown, 1942): It is referred to the level from which the viscus migrated in embryological development. It is epigastric for the stomach, duodenum, and gall-bladder; umbilical for the small intestine and appendix; hypogastric for the colon and urinary bladder. Pain from the rectum is felt vaguely about the site of the viscus.

\section{Pain from Nervous Tissues}

Before concluding it must be mentioned that clinically there is yet another type of pain derived from a lesion to the nervous tissues, central or peripheral. In the sense that it is never meant to serve a defensive purpose this pain is not physiological, and therefore is not considered further here.

\section{Conclusion}

From their clinical characters we can distinguish types of pain each of which is related to a definite group of tissues. These tissues have in common their relation to the body surface.

There must be in each segment a complex mechanism which presides over the manifestations of deep pain in that segment. This mechanism can be set in motion by certain visceral as well as somatic afferents. Their connexions must be such that the whole or the greater part of the mechanism can be set in motion even by limited injury; hence the pain is distributed widely and lacks discrimination. More superficial tissues have connexions which are more limited, while the connexions of the hollow abdominal viscera which have a mesial attachment in their embryonic life are distinct.

The connexions from the skin must be entirely different, as the pain differs not only in discrimination, power of location, and type of reflexes provoked, but also in quality.

\section{REFERENCES}

Brown, F. R (1942). British Medical Journal, 1, 543. Kellgren, J. H. (1938). Ibid., 1, 325. (1939). Clin. Sci., 4, 35.

Lewis, T. (1938). British Medical Journal, 1, 321

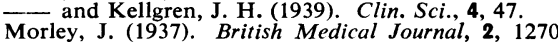

\section{SOME SOCIAL ASPECTS OF BURNS IN GLASGOW

\author{
BY
}

\section{ALEXANDER BROWN,* M.B., M.R.C.P.Ed. \\ E. LEWIS-FANING, $\dagger$ B.Sc., Ph.D.Lond. AND} MARTIN M. WHITTET, M.B.

\section{The Magnitude of the Problem}

The present high incidence of accidental burns in the civilian population, causing incapacity often of long duration, is a problem of great importance to the community in a state of total war. The study of the factors related to the occurrence of these injuries is of immediate interest. It should reveal also whether or not the high incidence may be expected to continue with the resumption of more normal conditions.

The progressive increase in the numbers of cases of burns admitted to hospital in Glasgow over a period of 100 years has been shown clearly by Dunbar (1934); it is probable, as Dunbar himself suggests, that part of this increase was due to a greater liability or inclination of burned patients to be treated in hospital in the latter part of the period surveyed, but that can hardly be the only factor concerned. Thus at the beginning of the period-in the decade 1833-42-the maximum number of cases admitted to the Glasgow Royal Infirmary in 12 months was about 80 . At that time the Royal Infirmary was the only Glasgow hospital to which patients with burns were admitted. In the last decade considered by Dunbar-1923-32 - a level of about 320 admissions in 12 months was reached, in spite of the fact that by this time two other large voluntary hospitals were treating these injuries. In the 10-year period 1933-42 a maximum yearly admission of 327 cases was attained. In the 14 months from June, 1942, to Aug., 1943, 1,803 cases of burns were treated in the burns unit of the Glasgow Royal Infirmary, and, of these, $303(16.8 \%)$ were admitted to the wards.

The following points should be noted as a preliminary to the considerations given later: (a) The Royal Infirmary, Glasgow, is situated in an industrial area and might therefore be expected to deal with a high proportion of industrial accidents. (b) The large numbers of infants and children treated for burns at the Infirmary do not represent all the

* Working with a part-time grant from the Medical Research Council.

$\dagger$ Member of the Medical Research Council's statistical staff. 
cases of burns in the district. Some would be treated at the Royal Hospital for Sick Children. (c) There is no reason to suspect preferential admission of one or the other sex to the burns unit of the Infirmary. (d) No cases of burns due to enemy action are included in this series.

\section{Incapacity due to Burns}

The 1,803 cases of burns are responsible for a considerable amount of incapacity among the wage-earners of the community. Analysis of the period of disablement in the various age groups of the 303 cases admitted to hospital is made in Table I. The figures indicating the disablement period include the total time spent in hospital and an average of 7 days during which outdoor treatment was given. This is a very conservative estimate.

TABlE I.-Age and Sex Distribution of 303 Cases of Burns admitted to Glasgow Royal Infirmary

\begin{tabular}{rr|c|c|c|c|c|c|c|c}
\hline \multicolumn{1}{r|}{ Age (Years) : } & $0-10$ & $11-20$ & $21-30$ & $31-40$ & $41-50$ & $51-60$ & $60+$ & Total \\
\hline $\begin{array}{l}\text { Males } \\
\text { Females }\end{array} \quad \cdots$ & $\ldots$ & 77 & 23 & 13 & 22 & 13 & 11 & 8 & 167 \\
\hline \multicolumn{1}{|c|}{ Total } &.. & 142 & 42 & 26 & 34 & 22 & 21 & 16 & 303 \\
\hline $\begin{array}{l}\text { Average period of } \\
\text { disablement (days) } \\
\text { per case }\end{array}$ & $34 \cdot 2$ & $36 \cdot 1$ & $44 \cdot 6$ & $39 \cdot 4$ & $38 \cdot 8$ & $39 \cdot 2$ & $32 \cdot 9$ & \\
\hline
\end{tabular}

In the age group 15-60 years the immediate result was a loss to the community of an average of 3,180 man-hours per month. In addition an average loss of 2,900 man-hours per month (calculated on the basis of an 8-hour working day) occurred in 668 cases of this age group treated wholly as out-patients. This loss of a total of 6,080 man-hours per month does not include a period of partial incapacity, the extent and duration of which it has been impossible to estimate nor does it take account of the remote effects of the more severe burns sustained during the first 15 years of life, or the remote effects, psychological and material, of severe disfigurement.

\section{Mortality due to Burns}

Some idea of the magnitude of the problem can be obtained from the recorded mortality figures in relation to burns in Britain and the United States of America (Table II). (The figures for Britain were obtained from the Reports of the Registrar-General, 1937; those for America from the U.S. Bureau, Vital Statistics, Special Reports, 1939, 7, 77, quoted

TABLE II.-Mortality from Burns in Great Britain and the U.S.A.

\begin{tabular}{|c|c|c|c|}
\hline & $\begin{array}{c}\text { Scotland } \\
1937\end{array}$ & $\begin{array}{l}\text { England and } \\
\text { Wales, } 1937\end{array}$ & U.S.A., \\
\hline $\begin{array}{l}\text { Population } \\
\text { Deaths from burns } \\
\text { Death rate per 10,000 }\end{array}$ & $\begin{array}{c}4,976,610 \\
256 \\
0 \cdot 51\end{array}$ & $\begin{array}{l}41,031,000 \\
1,318 \\
0.32\end{array}$ & $\begin{array}{l}128,000,000 \\
6,240 \\
0.49\end{array}$ \\
\hline
\end{tabular}

by McClure, 1939). The increasing numbers of burns noted by Dunbar, together with the attendant disability and these mortality figures, suggest that there is every prospect of the maintenance of this high incidence.

All differences mentioned in the present report have been tested for statistical significance, and are unlikely to have arisen as the result of chance unless it is specifically stated.

\section{Aetiological Factors}

Analyis of the cases treated at the Glasgow Royal Infirmary from June, 1942, to Aug., 1943, provides the following information.

TABLE III.-Age Incidence

\begin{tabular}{|c|c|c|c|c|c|c|c|c|}
\hline \multicolumn{2}{|l|}{$\begin{array}{c}\text { Age } \\
\text { Group } \\
\text { (Years) }\end{array}$} & $\begin{array}{c}\text { Population, } \\
1931 \\
\text { Census }\end{array}$ & $\%$ & $\begin{array}{l}\text { Total } \\
\text { Burns }\end{array}$ & $\%$ & $\begin{array}{c}\text { Rate } \\
\text { per } \\
1,000\end{array}$ & $\begin{array}{c}\text { Total } \\
\text { Admissions }\end{array}$ & $\begin{array}{l}\% \\
\text { Total } \\
\text { Cases }\end{array}$ \\
\hline $\begin{array}{c}0-\ldots \\
11-\ldots \\
21-\ldots \\
31-\ldots \\
41-\ldots \\
51-\ldots \\
61+\end{array}$ & $\begin{array}{l}\ldots \\
\ddot{0} \\
\cdots \\
\cdots\end{array}$ & $\begin{array}{r}225,334 \\
192,173 \\
188,215 \\
153,856 \\
130,875 \\
107,355 \\
90,653\end{array}$ & $\begin{array}{r}20 \cdot 7 \\
17 \cdot 7 \\
17 \cdot 3 \\
14 \cdot 1 \\
12 \cdot 0 \\
9 \cdot 9 \\
8 \cdot 3\end{array}$ & $\begin{array}{r}737 \\
392 \\
216 \\
181 \\
150 \\
77 \\
50\end{array}$ & $\begin{array}{r}41 \\
22 \\
12 \\
10 \\
8 \\
4 \\
3\end{array}$ & $\begin{array}{l}3.28 \\
2.05 \\
1.15 \\
1.18 \\
1.15 \\
0.72 \\
0.55\end{array}$ & $\begin{array}{r}142 \\
42 \\
26 \\
34 \\
\quad 22 \\
21 \\
\quad 16\end{array}$ & $\begin{array}{l}19 \cdot 3 \\
10 \cdot 7 \\
12 \cdot 0 \\
18 \cdot 8 \\
14 \cdot 7 \\
27 \cdot 2 \\
32 \cdot 0\end{array}$ \\
\hline All ages & . & $1,088,461$ & $100 \cdot 0$ & 1,803 & 100 & - & 303 & $16 \cdot 8$ \\
\hline
\end{tabular}

Age.- Of the total of 1,803 cases $41 \%$ occurred in the first 11 years of life, the proportion falling with each successive decade. Only $3 \%$ of the cases occurred in persons over 60 years of age (Table III). The very high incidence of burns in infants and children is shown by the fact that $53 \%$ of the cases occurred in the first 15 years and $25 \%$ in the first 3 years of life. On the basis of the age distribution of Glasgow's population in 1931, no excess of burns in children could have been suggested if only $20 \%$ had occurred in the first 11 years of life. The figure is, however, so much greater than this $(41 \%)$ that it is probably significant in spite of changes in the age distribution due to the outbreak of war. With regard to the age distribution of cases admitted to hospital, Table III also indicates that the admissions in each age group were not proportional to the total cases. Fewer patients under 21 and more of those over 21 -particularly in the ages above 40 -were admitted to hospital. These differences are significant, and the general impression is confirmed that, while the incidence of burns is higher at the younger ages, the injuries are more serious in the older patients.

Sex.-Of the 1,803 cases $56.3 \%$ were males and $43.7 \%$ femalesa ratio of $128: 100$. Of the 303 patients admitted to the wards, $55 \%$ were males and $45 \%$ females-a ratio of $123: 100$. Comparing the age distribution of male admissions with that of females, no real difference is demonstrable. In Dunbar's series, until 1865 the ratio of $200: 100$ obtained, and in the last decade considered by him the ratio was $100: 100$. Even if males and females were equally represented in the population of Glasgow it would be valid to deduce from the above figures an excess of male patients. But the 1931 Census figures show that females were slightly more numerous $(93: 100)$, and the withdrawal of men to the Services has probably emphasized the difference. It is concluded, therefore, that burns are more frequent among males than among females at every period of life, that this is equally true whether the cases are mild or severe, and that in these respects the position has altered but little in the last 10 years.

Cause of the Burn.- Information as to the cause of the burn was available only for patients admitted to the wards (Table IV). It is

TABLE IV.-Causes (303 Cases)

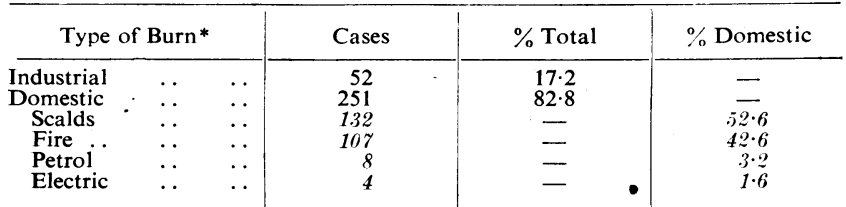

* No case of burn from enemy action or from conflagration is included in this series.

of interest to record that $13.9 \%$ of the domestic burns were due to hot tea.

Contributing Factors.-The chief intrinsic factors apart from age and sex are mental. They include epilepsy, alcoholism, and insanity with attempted suicide. The incidence of these factors in the admissions is shown in Table V. Mental dullness was noticed in many cases, but in the absence of reliable criteria for its assessment no accurate statement can be made on this point. The influence

TABLE V.-Contributing Factors in 303 Cases admitted to Hospital

\begin{tabular}{|c|c|c|c|c|}
\hline & & Cases & $\%$ Total & $\%$ in Patients over 15 \\
\hline $\begin{array}{l}\text { Epilepsy } \quad . \\
\text { Alcoholism } \\
\text { Attempted suicide }\end{array}$ & $\begin{array}{ll} & . \\
\cdots & \ldots \\
\cdots & \ldots\end{array}$ & $\begin{array}{r}12 \\
6 \\
2\end{array}$ & $\begin{array}{l}4 \cdot 0 \\
2 \cdot 0 \\
0 \cdot 7\end{array}$ & $\begin{array}{r}11 \cdot 7 \\
5.9 \\
1.9\end{array}$ \\
\hline
\end{tabular}

of these factors is more accurately shown in relation to the number of burns in adults. The term "alcoholism" refers here only to a degree of intoxication amounting to stupor at the time of burning. Many patients had taken alcohol in small amounts, and its relation to the accident was difficult to assess.

Time of Burning.-The time of sustaining the burns in 1,803 cases is shown in Table VI. As might be expected, the majority of patients sustained the injury between 9 a.m. and midnight. In addition, the six-hour period which shows the greatest number of cases is 2 to 8 p.m. The time of burning in relation to age is of particular interest (Table VII). Altogether, $386(21 \%)$ of the 1,803 patients received the burn after 8 p.m. Of this number $287(74 \%)$ were under 16 and $144(37 \%)$ were under 4 years of age. During the remaining part of the 24 hours only $47 \%$ of the burns were sustained at ages under 16 and only $22 \%$ at under 4 . Statistical tests show no difference between the two periods as regards age distribution among patients under 16 . But it is a grave reflection that while from midnight to 8 p.m. slightly less than half of the burns occurred in children under 16 , yet from 8 p.m. to midnighti.e., a time when one would expect young children to be in bed and safe-three-quarters of the burns sustained occurred at these young 
TABLE VI.-Time of Burning in 1,803 Cases

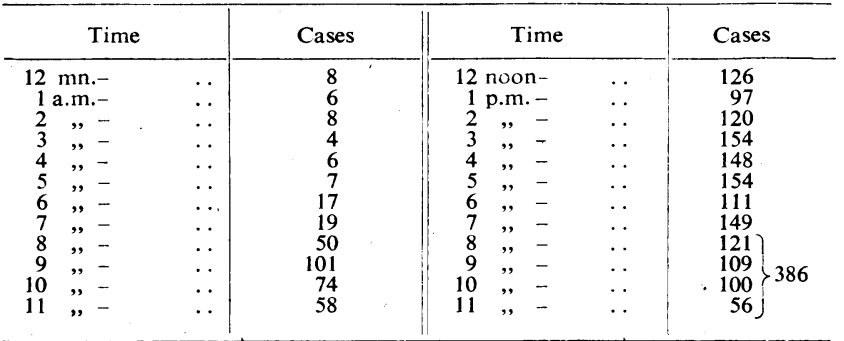

ages. The last column of the table shows that the proportion of burns occurring after 8 p.m. was highest between ages 1 and $2(38 \%$ of all burns at this age happened after 8 p.m.). The proportion varies between 23 and $30 \%$ at other children's ages, but for all ages over 16 combined it is as low as $11.7 \%$.

TABLE VII.-Age and Time Distribution (1,803 Cases)

\begin{tabular}{|c|c|c|c|c|c|c|c|c|}
\hline \multirow{2}{*}{$\begin{array}{c}\text { Age } \\
\text { Group } \\
\text { (Years) }\end{array}$} & \multirow{2}{*}{$\begin{array}{c}\text { Total } \\
\text { No. } \\
\text { Burned }\end{array}$} & \multicolumn{3}{|c|}{ Up to 8 p.m. } & \multicolumn{3}{|c|}{ After 8 p.m. } & \multirow{2}{*}{$\begin{array}{c}\text { Burns after } 8 \text { p.m } \\
\text { as \% of Total at } \\
\text { Each Age }\end{array}$} \\
\hline & & No. & $\%$ & & No. & $\%$ & & \\
\hline \begin{tabular}{cc|}
$0-$ &. \\
$1-$ &.. \\
$2-$ &.. \\
$4-$ &.. \\
$7-$ &.. \\
$10-$ &.. \\
$13-$ &.. \\
$16+$ &..
\end{tabular} & $\begin{array}{r}154 \\
202 \\
92 \\
147 \\
124 \\
104 \\
133 \\
847\end{array}$ & $\begin{array}{r}107 \\
126 \\
71 \\
104 \\
86 \\
74 \\
101 \\
748\end{array}$ & $\left.\begin{array}{l}7 \cdot 6 \\
8.9 \\
5 \cdot 0 \\
7 \cdot 3 \\
6 \cdot 1 \\
5.2 \\
7 \cdot 1\end{array}\right\}$ & $47 \cdot 2$ & $\begin{array}{l}47 \\
76 \\
21 \\
43 \\
38 \\
30 \\
32 \\
99\end{array}$ & $\begin{array}{r}12 \cdot 2 \\
19 \cdot 7 \\
5 \cdot 5 \\
11 \cdot 1 \\
9 \cdot 8 \\
7.8 \\
8 \cdot 3\end{array}$ & $74 \cdot 4$ & $\begin{array}{l}30 \cdot 5 \\
37 \cdot 6 \\
22 \cdot 8 \\
29 \cdot 2 \\
30 \cdot 6 \\
28.8 \\
24 \cdot 3 \\
11 \cdot 7\end{array}$ \\
\hline Allages & 1,803 & 1,417 & & $100 \cdot 0$ & 386 & & $100 \cdot 0$ & $21 \cdot 4$ \\
\hline
\end{tabular}

Extent of the Burn.-The average extent of the burn differed greatly in the sexes. This is seen to be due to the large proportion of males with burns of minor degree, and the greater proportion of severe burns in females (Table VIII). Only $13 \%$ of the males had

TABLE VIII.-Extent of Burn in 297 Admissions for which Data were available

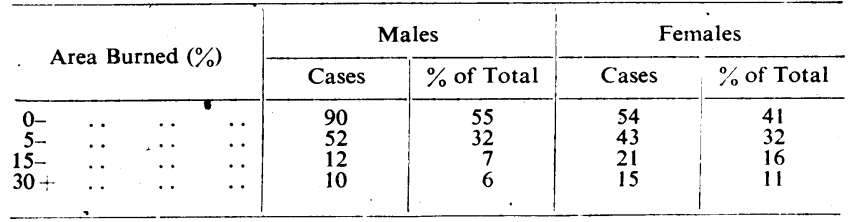

burns involving over $15 \%$ of the body surface, against $27 \%$ of the females. In addition, the average area of the burn was $8 \%$ in the males and $14 \%$ in the females. The tendency for the more severe burns to occur in the female may be related to the difference in clothing.

\section{Deaths due to Burns}

In the series of 303 admissions there were 40 deaths. Fatality rates by age and sex are given in Table IX. At every age group the rate is higher for females than for males, and this in itself indicates that the excess fatality rate for females at all ages combined-17.6\%, as compared with $9.6 \%$ for males-is significant. . Using broader groupings, the figures

TABLE IX.-Fatality Rates by Age and Sex in 303 Admissions

\begin{tabular}{|c|c|c|c|c|c|c|c|c|}
\hline \multirow{2}{*}{\multicolumn{3}{|c|}{$\begin{array}{c}\text { Age Group } \\
\text { (Years) }\end{array}$}} & \multicolumn{3}{|c|}{ Males } & \multicolumn{3}{|c|}{ Females } \\
\hline & & & Cases & Deaths & $\begin{array}{l}\text { Fatality } \\
\text { Rate }(\%)\end{array}$ & Cases & Deaths & $\begin{array}{l}\text { Fatality } \\
\text { Rate }(\%)\end{array}$ \\
\hline $\begin{array}{l}0- \\
11- \\
21- \\
31- \\
41- \\
51- \\
61+\end{array}$ & $\begin{array}{l}. \\
\because \\
\because \\
\because \\
\because \\
. \\
\end{array}$ & $\begin{array}{l}. . \\
\because \\
\because \\
\because \\
.\end{array}$ & $\begin{array}{c}77 \\
23 \\
13 \\
22 \\
13 \\
11 \\
8\end{array}$ & $\begin{array}{l}8 \\
0 \\
0 \\
2 \\
1 \\
1 \\
4\end{array}$ & $\begin{array}{c}10 \cdot 4 \\
0 \\
0 \\
9 \cdot 1 \\
7 \cdot 7 \\
9 \cdot 1 \\
50 \cdot 0\end{array}$ & $\begin{array}{r}65 \\
19 \\
13 \\
12 \\
9 \\
10 \\
8\end{array}$ & $\begin{array}{l}9 \\
2 \\
0 \\
2 \\
3 \\
1 \\
7\end{array}$ & $\begin{array}{c}13 \cdot 8 \\
10 \cdot 5 \\
0 \\
16 \cdot 3 \\
33.3 \\
10 \cdot 0 \\
87.5\end{array}$ \\
\hline \multicolumn{2}{|c|}{ All ages } & .. & 167 & 16 & $9 \cdot 6$ & 136 & 24 & 17.6 \\
\hline $\begin{array}{l}0- \\
21- \\
51+\end{array}$ & $\begin{array}{l}\because \\
\because \\
\therefore\end{array}$ & $\begin{array}{l}\because \\
\because\end{array}$ & $\begin{array}{r}100 \\
48 \\
19\end{array}$ & $\begin{array}{l}8 \\
3 \\
5\end{array}$ & $\begin{array}{r}8 \cdot 0 \\
6 \cdot 2 \\
26.3\end{array}$ & $\begin{array}{l}84 \\
34 \\
18\end{array}$ & $\begin{array}{r}11 \\
5 \\
8\end{array}$ & $\begin{array}{l}13 \cdot 1 \\
14.7 \\
44.4\end{array}$ \\
\hline
\end{tabular}

suggest that the fatality rate is much higher at the older ages; but the total number of deaths is too small for valid statistical tests, so that this conclusion must be accepted with reserve.
When the age distribution of the deaths in this series is compared with that of deaths from burns in Scotland as a whole for $1941^{*}$ no real difference can be demonstrated (Table X).

TABLE X

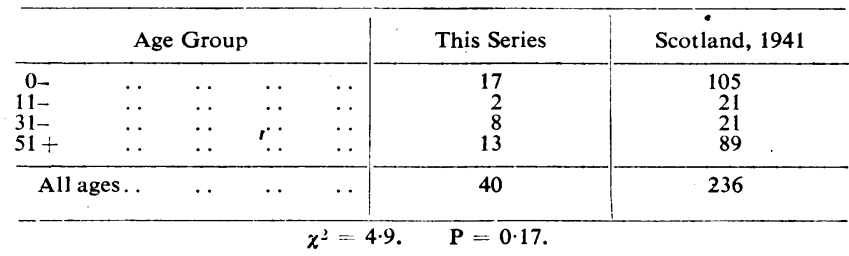

It is possible, therefore, to arrive at a very crude estimate of the number of admissions to hospital from burns in the whole of Scotland. For if 40 deaths arose from 303 admissions, then 236 deaths would have arisen from 1,788 cases of burns serious enough to be admitted to hospital.

The mortality from scalds was lower than that of other types of domestic burn. In 132 cases of scald $9(6.8 \%)$ deaths occurred, whereas 29 deaths occurred in the other 119 domestic cases $(24.4 \%$ mortality; difference, $17.6 \pm 4.5 \%)$. Only 2 deaths occurred as a result of industrial burns $(3.8 \%$ mortality, as compared with domestic $15.1 \%$; difference $=11.3 \pm 5.2 \%$ ).

\section{Summary and Conclusions}

This report gives a statistical analysis of 1,803 cases of burns treated in the burns unit of the Glasgow Royal Infirmary between June, 1942, and Aug., 1943, particularly in regard to 303 patients who were admitted to hospital. It is supplementary to the series of papers published in "Studies of Burns and Scalds: Reports of the Burns Unit, Royal Infirmary, Glasgow, 1942-3" (Med. Res. Cncl. Sp. Rep. Ser. No. 249, 1944).

The incidence of burns was high at the younger ages, but the results were more serious in older patients. The incidence was higher among males, but fatality was greater among females.

The injuries were sustained most frequently between 2 p.m. and 8 p.m., but the incidence of burns at a late hour was greatest in the early age groups. Between midnight and $8 \mathrm{p} . \mathrm{m}$. less than half the burns sustained occurred in children under 16 , but between 8 p.m. and midnight three-quarters of the accidents occurred at these young ages. The grave social implication of this finding is stressed.

We are indebted to Mr. A. M. Clark, surgeon in charge of the burns unit, for permission to publish these findings; and to Dr. L. Colebrook, Prof. J. W. S. Blacklock, and Prof. M. Greenwood for much helpful criticism.

\section{REFERENCES}

Dunbar, J. (1934). Glas. med. J., 122, 239

McClure, R. D. (1939). J. Amer. med. Ass., 113, 1808.

\section{CHRONIC INTRACEREBRAL HAEMATOMATA THEIR PATHOLOGY, DIAGNOSIS, AND TREATMENT BY}

G. F. ROWBOTHAM, F.R.C.S.

Surgeon-in-Charge, Neurological Dept., Newcastle upon Tyne General Hospital

AND

A. G. OGILVIE; F.R.C.P.

Hon. Assistant Physician, Royal Victoria Infirmary, Newcastle upon Tyne

Intracranial haemorrhages may result from rupture either of normal or of diseased blood vessels. Apart from tearing by accidental forces, healthy cerebral blood vessels rarely burst ; on the other hand, when weakened by disease or by congenital malformation the walls of a cerebral blood vessel may give way when subjected to normal stresses and strains.

Spontaneous subarachnoid haemorrhage is a well-known cerebral catastrophe, diagnosis readily being made by lumbar puncture. The clinical picture is usually characteristic. A previously healthy young or middle-aged person is struck with a sudden and severe pain in the head which rapidly radiates into the neck and may reach as far as the fingers and toes. Consciousness may or may not be impaired, and when impairment does occur this may be immediate or delayed. Cranial nervé and limb palsies may or may not develop. 